\title{
International Aid and Development NGOs in Britain and Human Rights since 1945
}

The United Kingdom's international aid and development community owes its origins to the humanitarian impulse. Many of the principal non-governmental organizations were the product of relief initiatives undertaken during or at the end of war. Save the Children was founded in 1919 by the sisters Dorothy Buxton and Eglantyne Jebb. Oxfam began life as the Oxford Committee on Famine Relief in 1942 as one of a number of networked Famine Relief Committees set up to deal with wartime refugees. Christian Aid was established in its original form in 1945 as Christian Reconstruction in Europe. And amid an internationalist spirit that inspired many individuals from across the political spectrum, War on Want was created in 1952, emerging out of the socialist publisher Victor Gollancz's Association for World Peace, created the year previously.

It was precisely such an internationalist spirit that provoked much of the flurry around human rights initiatives in the lead-up to the signing of the United Nations Charter in 1945 and the publication of the Universal Declaration of Human Rights in 1948. Although recent work has demonstrated the imperial legacies and sovereign state interests that shaped this human rights framework, the emphasis on rights was clearly an important spur to many progressive and internationalist-minded men and women who joined and ran what would increasingly be referred to as NGOs. ${ }^{1}$ Yet as with many other civil society organizations, the language of rights was curiously absent from the everyday publications and policies of Oxfam, Christian Aid and War on Want. The inspiration to relieve human suffering owed more to Christian fellowfeeling than it did to the secular recognition of people's universal and inalienable rights.

By the end of the twentieth century, however, faith-based and secular humanitarianism had given way to a model of development based on human rights. Oxfam led the way. In its strategic plan for $200 \mathrm{I}-4$, it positioned its "rights-based approach" as the underlying mechanism with which to achieve economic and social justice the world over. The rights it listed deliberately covered civil and political rights as well as economic and social rights. ${ }^{2}$ Others produced similar statements. Indeed, it is difficult to escape the focus on human rights that now dominates the core missions of NGOs. War on Want declares, "We campaign for human rights against the root causes of global poverty, inequality and injustice."3 Christian Aid takes "the side of poor and marginalised people as they struggle to realise their civil, political, economic, social and cultural rights." 4 Action Aid UK supports "the poorest and most vulnerable people to fight for and gain their rights to food, shelter, work, basic healthcare." 5 The 
World Development Movement recognizes that tackling poverty can only be done alongside an approach that shows "respect for human rights." And central to the work of One World Action is "the belief that defeating poverty goes hand in hand with promoting human rights and good democratic government."

Many more examples might be cited, and not only from the United Kingdom. As historians we ought not to be surprised at this trend toward a full integration of human rights frameworks from a position, several decades previously, where they were not mentioned at all. Indeed, as Samuel Moyn has most persuasively argued, rights failed to capture the global imagination until the I970s, not least because of the disputes between Cold War factions over the meaning and emphasis to be given to civil and political rights and economic and social rights. Only in that decade did rights then begin to mobilize social movements around the world, epitomized most clearly in the award of the Nobel Peace Prize to Amnesty International in 1977. From then on, rights talk has increasingly become the only game in town as other forms of universal political systems have fallen to the wayside. Indeed, Moyn has termed human rights the "last utopia," principles which originated as an alternative to ideology but which have, nevertheless, come "to take on the grand political mission of providing a global framework for the achievement of freedom, identity, and prosperity." 8

Within this narrative the adoption of a human rights approach by development NGOs might simply be a footnote in a much broader history of the belated ascendancy of rights talk. Yet a case study on the UK is illuminating because it allows us to see how human rights came to pervade the mission statements of these increasingly prominent sociopolitical actors. A crucial question concerns whether NGOs themselves were the drivers of human rights or whether they were recipients-passive or otherwise - of rights discourses promoted in other arenas.

What follows is as much a transnational as a national history, a distinction blurred all the more because of the worldwide prominence of British-based NGOs in this sphere. The issues affecting Oxfam, Christian Aid, and War on Want-the three organizations, among others, examined in greater depth below-were comparable to those that have faced a similar history elsewhere. The International Committee of the Red Cross is perhaps the example with the longest history, but other Northern-based big international NGOs such as the U.S.-based Care International, NOVIB (the Dutch organization for international aid), Norwegian Church Aid or the Danish ChurchAid, have come to espouse a similar rights-based agenda. ${ }^{?}$

The argument put forward here is that human rights frameworks have opened up as well as restricted the field of operations of NGOs. NGOs like to believe that their adoption of a rights-based approach is the culmination of an intellectual journey that began with their exploration of alternative development. The first half of this essay accordingly recounts the history of NGOs almost on their own terms. It tells how they themselves have perceived the changes in their development thinking and how they came to adopt a rights-based perspective as a logical consequence of the changing political environment and their own intellectual explorations. International aid NGOs began as humanitarian agencies, transformed into advocates of alternative paths to development, and then, as they would like to see it, became proponents of a rights- 
based approach in order to provide an intellectual coherence to their range of activities and approaches.

However, the adoption of rights-based approaches has been much more intertwined with the processes of global governance. Indeed, the second half of this essay provides a much more problematic history of the turn to rights. It will be shown that the advances and changes in development thinking often occurred elsewhere-at the $\mathrm{UN}$, in universities, in the Bretton Woods institutions-and NGOs became the conduits through which these ideas were disseminated. As such, the articulation of rights-based approaches by NGOs had as much to do with actors other than NGOs themselves. The explanation for this lies in the relationship NGOs have come to adopt with the official institutions of national and global governance. Here, rights talk has served a variety of interests and has become intertwined with new vocabularies of development in which the freedom of NGOs to act can be restrained as well as transformed. NGOs have become intertwined with the broader processes of political and economic globalization, including those aspects of which they have been open critics. Consequently, while NGOs can still successfully pursue such goals from a rights-based perspective, it is also clear that rights do not provide the underlying ideological or intellectual unity to which many aspire. Rights enable development activists to articulate a language for change, but it is a change all too often dictated by far more powerful institutions and intergovernmental organizations. These bodies have very different agendas from NGOs in their planned goals of development, marked most clearly in their prioritization of economic rights over the social rights espoused by NGOs.

\section{Toward NCOs Based on Rights}

The big international aid and development NGOs do not pretend that rights have always been integral to their work. They do, however, like to construct narratives in which their origins in relief work grow seamlessly into promotion of alternative paths to development, followed by an increasing political advocacy role and the consequent adoption of rights-based approaches. For all that NGOs did not speak the language of rights before the I970s, rights are nevertheless now presented as the logical and progressive outcome of decades of development initiative. It is worth detailing the key aspects of this path to rights.

In Britain, religion played a significant role in the creation of international aid and development NGOs. Missionary movements stretch back to the eighteenth century, while Quaker, Anglican, and Jewish relief efforts followed in the wake of the British Red Cross in the late nineteenth century. ${ }^{10}$ The Second World War was particularly crucial. Although it is an avowedly secular organization now, the two principal organizers of the first meeting of Oxfam in October 1942 were the Anglican cleric Canon Richard Milford and the Quaker-inspired philanthropist Cecil Jackson-Cole, who believed Christianity and entrepreneurialism could be combined. While Gilbert Murray placed a more secular, liberal-humanist stamp upon Oxfam's early work in Greece, the organization itself received much support from Quakers, and it relied on the institutional support structures provided by the churches. ${ }^{11}$

Christian Aid has its origins in the World Council of Churches (WCC). In 1945, 
one of the WCC's many bodies, the Department of Reconstruction, merged with the European Central Bureau for Inter-Church Aid (established in 192I) to become the Department of Reconstruction and Inter-Church Aid (alternatively termed Christian Reconstruction in Europe). This became a department of the British Council of Churches, changing its name to the Inter-Church Aid and Refugee Service in 1949, and later Christian Aid in 1964, as it identified itself with the increasingly prominent "Christian Aid week" begun in 1957. ${ }^{12}$ It would soon be joined by CAFOD (the Catholic Agency for Overseas Development) in 1962, with which it has often collaborated, and by the even more overtly missionary body Tearfund, which began as the Evangelical Alliance Relief Fund in $1968 .^{13}$

Religion rather than rights was thus more prominent in the establishment of British development organizations. Even the labor movement's body, War on Want, relied on Christian support and assistance. One of its founders was the Anglican clergyman Canon John Collins, who would later help found the Campaign for Nuclear Disarmament, and its grassroots network of local support groups relied on Quakers and the other churches. While it obtained the support of the later prime minister Harold Wilson, it also counted on the Iona Community, Christian Action, and spiritually based older peace movements such as the Fellowship of Reconciliation. ${ }^{14}$ Such networks suggest for the rise of NGOs a characteristic similar to the Labour Party general secretary Morgan Phillips's much quoted adage about the history of British socialism: that it owed more to Methodism than it did to Marx. ${ }^{15}$

Rights, then, simply did not appear in the rhetoric of these organizations in their formative years. When they sought an intellectual underpinning for their work, they were just as likely to turn to religious principles as they were to secular human rights. The irony here is that, according to Samuel Moyn, the World Council of Churches was one of the few organizations to engage seriously with rights at this time. To the extent that more conservative elements within the WCC did promote rights as an early Cold War tactic against the Soviets, such thinking did not later percolate down to Christian Aid. Indeed, NGO work at this time was focused on small-scale development projects organized with partners abroad, else they continued to respond to emergencies and disasters. In 1963, for instance, the British Red Cross, Christian Aid, Oxfam, the Save the Children Fund, and War on Want came together to form the Disasters Emergency Committee, which has coordinated fundraising during emergencies to the present day.

This is not to say that the NGOs were not engaging with debates about the deeper structural issues lying behind both poverty and the socioeconomic relations which often gave rise to emergency situations. In 1968, Oxfam, Christian Aid, and the Overseas Development Institute, as well as the NGOs connected to the Voluntary Committee on Overseas Aid and Development (an umbrella organization established in 1965 to assist interaction with the new Ministry of Overseas Development), published the Haslemere Declaration. This committed British NGOs to a more political role, as it called upon the government to increase both the quantity and quality of aid. In addition, it called for adjustments to the entire system of international trade, which—as NGOs would continue to claim for the next halfcentury-favored those nations that were already rich. The signatories to the decla- 
ration were eager to show how far they had come from the relief organizations set up during World War II. Charity, they claimed, was not enough: "Too often it is the equivalent of tossing sixpence in a beggar's cap: money given by those who have no intention of changing the system that produces beggars, and no understanding that they are part of it." 16

Yet as the Haslemere Group began to take on board the issues that would become the hallmarks of future campaigns against unfair terms of trade, protectionism, the debt regime, and the ability of sovereign states to determine their own paths to development, they did so according to a notion of citizenship still bounded by the nationstate rather than the universalist rights of humanity. They called for a "coherent and united movement," but it was to be based on the ability "to respond realistically to the desperate human need of the poor world." 17 That is, the North and the South were not to be acting in concert, but the former was to respond to the needs of the latter. The crucial distinction was epitomized in the one reference to human rights made in the Haslemere Declaration. Concerned with the health of British society too, the pamphlet declared that "a system that can no longer respond to the individual abroad will deny human rights to those at home." ${ }^{18}$ In this perhaps ill-intended sentence, the implications are nevertheless clear: while the disadvantaged in the North have rights, the disadvantaged in the South have needs.

The academic and intellectual contexts within which the NGOs were engaged were those that had become increasingly critical of the technocratic nature of official aid programs. They drew on the works of the newly emerging academic discipline of development studies, such as at the University of Sussex's Institute of Development Studies, as well as of established development economists such as Barbara Ward and Gunnar Myrdal. ${ }^{19}$ The latter's Economic Theory and Under-Developed Regions, first published in 1957, gave a strong impetus to NGOs' belief in the power of southern states to set and execute their own autonomous development projects. ${ }^{20}$ Support for national sovereignty, though, was mixed with an admiration for small-scale development. E. F. Schumacher was a major influence, as was Ivan Illich's skepticism about professional experts. $^{21}$

Particularly influential was the idea of consciousness-raising or "conscientisation" associated with the Marxist-influenced Brazilian writer Paulo Freire. In Pedagogy of the Oppressed, first published in 1968 and translated into English in 1970, he argued that the oppressed will only achieve their freedom when they play a role in bringing it about themselves. ${ }^{22}$ Such an analysis was readily absorbed within a wider framework of liberation theology associated with the 1968 Conference of Latin American Bishops in Medellin, Colombia, which taught the poor dignity and respect and their own potential for change. Freire's impact "on the more radical minds in Oxfam was profound." 23 Oxfam supported the development of liberation theology, particularly through the later funding of the Jesuit Center of Study and Social Action in Salvador. In May 1974, Oxfam's staff reading group pursued its own "consciousness-raising exercise" led by Reggie Norton, the Latin American field secretary, who had absorbed much radical thought and theology. ${ }^{24}$

How such ideas translated into development action was through the support for small-scale projects. Particularly attractive to the British NGOs were those reforms 
supported by nation-states which involved piecemeal change at the micro-level, and which were tied to localized paths to development set out by the sovereign state. In the I96os, War on Want and Oxfam supported the Gramdam land reform movement initiated by the Gandhian J. P. Narayan. This had resulted in the pooling and redistribution of land in 50,000 Indian villages. Likewise, British NGOs supported Julius Nyerere's experiments with Ujamaa. It was a link facilitated by Trevor Huddleston, formerly bishop of Masasi in Tanganyika in 196I, but then president of the UK AntiApartheid Movement and later chair of War on Want. ${ }^{25}$ As more substantial organizations, Oxfam and Christian Aid were able to lend even greater support to Nyerere's initiative. Indeed, so committed were the organizations that they remained "seduced by the rhetoric of Ujamaa" even when, as the I970s progressed, the socioeconomic transformation became increasingly authoritarian, involving the "brutal dislocation of rural lives." 26

By the I970s, NGOs were increasingly beginning to trumpet their "comparative advantage" obtained through small-scale, grassroots, nontechnocratic development initiatives. They would also come to be praised by the official agencies, so much so that the 1980 os became something of a golden age for NGOs. ${ }^{27}$ In 1988, following several years of cooperation with NGOs, the Organisation for Economic Co-operation and Development was able to explain, "To us on the official side the NGO sector represents an educator of our publics, an aspect of our support, the origin of some of our policy, a welcome financial contribution, the source of insights on methodology and a vehicle for administering a portion of our official assistance." ${ }^{28}$ According to Bertrand Schneider in his influential The Barefoot Revolution: A Report to the Club of Rome (1988), NGOs had become the "moving force behind what are often termed 'microprojects,' small-scale, community- or village-based development projects under way in a hundred different countries." 29 NGOs had become a "significant force for development" from which the official agencies should learn, especially from how NGOs had become "better adapted to the needs of the concerned populations." 30

It was this alternative approach to development espoused by NGOs that supposedly fed through into a broader rights-based agenda. For all their strengths, the weaknesses of the small-scale project and a local grassroots approach were also clear. They could lead to isolation and a failure to learn from mistakes and successes. The projects were so diverse that it was difficult to establish common ground rules necessary for "scaling up" such that the advantages of the alternative approach to development could be made available to a larger population. Moreover, if the work on the ground did not have an impact on the structural organisation of politics and the economy, then the long-term benefits of a successful project could be lost. Here NGOs had increasingly come to recognize the importance of political lobbying and advocacy as a central component of their work.

Such a change in the direction of the NGO_-away from providing short- and long-term relief and assistance to one of political intervention-proved controversial. Most NGOs underwent a period of intense self-reflection, resulting in the loss of key staff in some instances. The examples are legion and are not just confined to the development sector. Countless NGOs in the late i960s and I970s recognized the importance of political lobbying and took the awkward and controversial steps to 
change the focus of their work. ${ }^{31}$ For instance, in 1970 Oxfam director Rev. Nicholas Stacey, inspired by the work of Des Wilson at Shelter, sought to increase Oxfam's political role once more. Unable to convince the Council of Management to follow his lead, he felt compelled to resign, later explaining in a letter to the Times that he had done so "because I think [Oxfam] has missed an opportunity of attempting to influence events which will dominate our history in the remaining years of this century, and I do not fancy myself primarily as a fund raiser." 32

However, the principle of political intervention was recognized relatively early. One year after the Haslemere Declaration, several UK charities, led by Christian Aid and Oxfam, decided to build on the momentum begun by numerous local World Development and Poverty Action Groups to create Action for World Development, an independent body that would be free of UK charity legislation. It soon became the World Development Movement, an outlet for the many local ginger groups that Oxfam and Christian Aid had helped create, and which would be influenced by writers such as Marx, Frantz Fanon, and the radical French agriculturalist René Dumont. To complement local activism and central lobbying, Christian Aid and Oxfam further went on to launch the New Internationalist in $1973 .{ }^{33}$ More controversially, War on Want embarked on a series of high-profile exposés of systematic inequities in the global trading system, from the inappropriate sale of breast milk substitutes in the developing world to the appalling conditions on many tea plantations. ${ }^{34}$ Such activities drew increasing attention from the authorities, and War on Want, as well as a number of other NGOs, regularly came under the scrutiny of the Charity Commissioners. ${ }^{35}$

However, increased political advocacy could not achieve much if it was not consistent and coherent. This is where a human rights framework began to appear attractive. It seemed to offer a means by which the grassroots work of the NGOs could be translated into a global agenda. Of course, there was not a complete vacuum of rights talk within NGOs. If they were not integral to their project work, NGOs had recognized that civil and political rights often formed certain absolute values which they could not simply ignore. Christian Aid, for instance, had supported the Rev. Park Hyung-kyu, a human rights activist in South Korea, for a number of years in the 1970s. ${ }^{36}$ War on Want devoted much of its campaigning work in the late I97os and early 1980 s to the abuses taking place in Nicaragua and constantly reached out an arm of solidarity to struggles for workers' rights around the world. ${ }^{37}$ Unsurprisingly, the rights of children had been a concern for many NGOs (especially Save the Children) long before the UN passed a Convention on the Rights of the Child in 1989. ${ }^{38}$ An interest in social and economic rights was initially closely tied to a concern for women's rights. Oxfam established a dedicated Gender and Development Unit in 1985, the same year as the World Conference on the Advancement of Women. ${ }^{39}$ And War on Want worked closely with ordinary women across Latin America throughout the I980s following an overtly feminist agenda, and it established a spin-off, Women Working Worldwide, in $1985 .{ }^{40}$

The problem was to find the intellectual underpinning to connect all these issues. For Oxfam, as it likes to imply, this was provided by the writings of the economist and philosopher Amartya Sen. Sen's model of development is based on enhancing 
people's freedoms — political, social, and economic — such that their capabilities for pursuing their own advancement will be released and expanded. ${ }^{41}$ For NGOs, Sen's thinking created the link between grassroots participation of the poor in their own development (which the NGOs had long advocated) and a rights-based approach. It was a connection facilitated, so it has been claimed, by Sen's own position as honorary president of Oxfam from 2000 to 2002. According to one analysis of rights-based approaches, Sen "prodded the organisation to rethink its strategy for facilitating development." ${ }^{42}$ However, his work while at Oxford University in the 1980s had demonstrated to NGOs the connections between democracy and the absence of famine. Most significantly, it has been argued that in order for his capabilities approach to be "meaningful, such principles must be grounded in a conception of rights that strengthens the capacity of citizens to make legitimate claims of government." 43

Once the Cold War ended in 1989, the growing ascendancy of liberalism created an environment conducive to rights talk. At the same time, NGOs stepped up their presence. Oxfam began to better coordinate its national offices, such that it was able to successfully lobby various intergovernmental agencies. The World Bank was said to have regarded Oxfam as a "grown-up NGO" and "the unofficial leader of the nongovernmental aid groups.”44 British NGOs participated forcefully in new global campaigning networks, from the International Baby Food Action Network in 1979 to the Debt Crisis Network in 1988, through to Jubilee 2000 in $1997 . .^{45}$

Significantly, NGO agendas for the I990s were couched in terms of human rights. In I993, War on Want launched its three-year campaign "A human right to development," which built on the work on women and development to link economic and social rights with civil and political rights. ${ }^{46}$ In the same year, Oxfam declared itself a "partnership of people" working together for "basic human rights." 47 Oxfam could still claim that it was "not a dedicated human rights organisation" in the same way as, for instance, Amnesty International, but it could also claim that rights were central to what it did. ${ }^{48}$ In 1995 , however, rights began to be used to shape the entire operations of NGOs. They cast off their "human needs" approach and translated this_-almost line by line_-into a "human rights" approach. Oxfam issued its Global Charter for Basic Rights in 1995, the very term "basic" betraying the legacy of the basic needs approach that dominated much development thinking in the r970s. But importantly, basic human needs had now become a list of ten economic and social rights. These included those to a home, clean water, enough to eat, a safe environment, protection from violence, equality of opportunity, a say in one's future, an education, a livelihood, and healthcare. ${ }^{49}$ Similarly, War on Want asserted that human rights were "inalienable and indivisible. Civil and political rights; economic, social and cultural rights - are essential and depend on each other." 50 With the appointment of a new director in 1995 with a background in the labor movement, older concerns for workers' rights were incorporated into the new broader human rights framework. Its 1995 publication Iraq: Sanctions and Human Rights, for instance, aimed to show that "human rights . . . include these other social, cultural and economic rights."

Slightly later, Christian Aid followed suit. Its leader found few problems in marrying its religious principles to a human rights agenda, just as the WCC had done 
after the Second World War. In 1998, the fiftieth anniversary of the UDHR, Christian Aid affirmed "the equal rights of all people as 'made in the image of God." "52 In addition to established core civil and political rights, it too went on to list a set of economic and social rights almost identical to Oxfam's of three years previously. By this time, however, the language of rights was everywhere in development NGO circles, not least because of the increased interaction and cooperation between the principal bodies and because authors of NGO reports might write for more than one organization. Rights were proving attractive to so many NGOs because they enabled the "problems" encountered by development workers, such as contaminated water or malnutrition, to be tackled politically. Rights made it clear that such problems were violations caused by human agency, though in a language that seemed more politically_or, at least, ideologically_neutral. Significantly, while many NGOs underwent a process of intense soul-searching in their decisions to be more political in the 1970s, later on, when that politics was reoriented to a rights-based approach, the criticisms from within the sector were much less profound.

By the end of the millennium, then, rights had become the standard shared language of aid and development NGOs. ${ }^{53}$ If Oxfam leads the way, it is closely followed by others such as ActionAid who see rights as logically following from its established grassroots work: "Our long-standing commitment to participation, and our drive for sustainability lead us to adopt a rights-based approach in all of our work." 54 And for CARE, which has collaborated closely with Oxfam on rights, it enables the NGOs' work on the ground to connect with the entire system of global governance: "A rights-based approach recognises poor, displaced and war affected people as having inherent rights essential to livelihood security — rights that are validated by international law." 55 As we will see in the following section, though, it is precisely this confluence of the rhetoric of NGOs and supranational organizations that points to a different explanation for the spread of rights talk.

\section{The Nexus of Development and Rights}

A counternarrative to the adoption of rights-based approaches by NGOs comes from a focus on global trends in development thinking. Here NGOs are not so much the instigators as the followers of development thought and practice. No matter how big international NGOs have become, their interventions on the ground have largely paled into insignificance next to the operating budgets of the official development agencies. Indeed, if one were to pass over NGOs entirely, one could still write a credible history of the "right to development" that focused exclusively on official agencies and intergovernmental institutions.

Such an account would begin with a similar absence of rights in development talk in the immediate post-Second World War period. President Truman's Four Point speech of January 1949 introduced the concept of "underdevelopment" to a global audience. But this was a scientific and technical phrase which depoliticized the issue away from either duties or rights and spoke instead to the technical measures which could be used to increase a country's GDP. Although former imperial powers such as Britain retained a legal obligation to provide assistance (through the Colonial Development and Welfare Acts of 1929 and 1940), the momentum was now to reside with 
the specialist agencies of the UN and the development experts who assisted U Thant in producing Proposals for Action in $1962 .{ }^{56}$

At the end of the first development decade, the UN observed that human rights were given scant attention in development initiatives. Rights at this stage were only to be respected, not extended or protected. Article 2 of the 1969 Declaration on Social Progress and Development did establish an important precedent in claiming, "Social progress and development shall be founded on respect for dignity and value of the human person and shall ensure the promotion of human rights and social justice," but this was rarely picked up at the time. ${ }^{57}$ Instead, the interests of the poorest were usually understood in terms of needs. This had long been a concern of the NGOs and may well have proved influential, especially as the United States and the Western agencies saw in "basic human needs" an opportunity to counter the increasingly vociferous demands of the nonaligned movement and the New International Economic Order endorsed by the UN General Assembly in 1974. ${ }^{58}$

During the I970s, the human rights bodies at the UN, although still principally focusing on political and civil rights, moved in the direction of a right to development. This came at a time when human rights were being increasingly linked to international diplomacy, particularly under the Carter administration. UNCTAD had referred to a right to development as early as 1972. By the end of the decade, in 1979, the Commission on Human Rights affirmed the existence of the right to development, and the secretary-general issued a definition of development to which human rights were "fundamental." 59

Human rights NGOs, rather than development NGOs, picked up and ran with the baton given to them by the UN. In I98I, the International Commission of Jurists (ICJ) supported the basic rights approach to development. At its conference "Development and the Rule of Law" held in April of that year, the NGO declared that a needs-based approach relegated the poorest nations to a relationship of dependency. Only if those needs were translated into rights — that is, into claims upon the entire economic and political structure that gives rise to absolute poverty in the first placecould a basic needs approach become effective. Marking an important transition in the history of human rights NGOs, if not development NGOs, the conference committed the ICJ to moving on from a focus on political and civil rights to one that embraced economic and social rights too, especially through a broad-ranging "right to development" that affirmed many of the principles of the NIEO. ${ }^{60}$

Many have commented that the one lasting legacy of the nonaligned movement was the establishment of a collective - that is, not an individual's - "right to development." If most of the other objectives of the NIEO were never met, especially in an era of structural adjustment and expanding debt, the right to development obtained a certain momentum within the institutions of global governance during the 1980s. It was adopted by African states in the 198I African Charter on Human and People's Rights. It continued to be promoted within the UN despite the opposition of the United States, and in 1986 the General Assembly passed a Declaration on the Right to Development. ${ }^{61}$ As a concept it was then ready to be used by those joining in the backlash against the structural adjustment programs kick-started by UNICEF's Adjustment with a Human Face (1987). It would culminate with the World Conference 
on Human Rights in June 1993 and the issuing of the Vienna Declaration on Human Rights by the General Assembly, which reiterated the secretary-general's 1979 pronouncement that human rights were "fundamental" to development. ${ }^{62}$

From this point on, the right to development permeated countless other institutional settings. In 1998, the delegates to the General Assembly, celebrating the fiftieth anniversary of the UDHR, proposed that the Vienna Declaration be on a par with the UDHR. In 2003, the Nobel Symposium on the Right to Development and Human Rights to Development met not to question the validity of the concept but to elaborate further on the connections between rights and development. ${ }^{63}$ As well as being integral to the work of the UNDP, UNICEF, and other UN agencies, the rights-based approach had been adopted by various national official agencies such as the UK's Department for International Development. ${ }^{64}$

How, then, do we reconcile this narrative with the NGOs' own accounts of their adoption of a rights-based perspective? Did the concept of rights represent a genuine intellectual engagement with capabilities theory that enabled NGOs to politicize and scale up their grassroots work? Or did NGOs merely employ a fashionable term and claim an intellectual coherence only later? The answer lies in the lead provided by many of the official agencies which NGOs have closely followed and, in more recent decades, with which they have been more formally aligned.

For all that NGOs like to think that they have set the agenda or operated at the forefront of rights-based initiatives, their relationship to rights is much more problematic. In what follows, it will firstly be shown that NGOs have tended to hang on the coattails of both development thinkers and official development initiatives. This has meant, second, that the context for the adoption of rights-based approaches has been created by institutions other than the NGOs themselves. To be sure, NGOs deliberately embraced a discourse of rights because it seemed to follow from their own established focus on participation and grassroots development. But doing so meant that they were agreeing to communicate in a language influenced and directed by actors and interests far more powerful than themselves. Crucially, it meant that they would become as much the products as the creators of a system of global governance increasingly predominant from the late r980s.

Ever since their foundation NGOs have relied on the initiatives of intergovernmental agencies to lend authority and momentum to their activities. For those operating in the Second World War, they often worked closely with the United Nations Relief and Rehabilitation Administration. The postwar official aid agencies have tended to set the agenda and launch the initiatives that the NGOs have chosen to support. For instance, the UN World Refugee Year in 1959 was an incredibly powerful stimulus to British NGOs. Christian Aid used it to expand substantially its fundraising activities, Oxfam was given a key role in the official activities in Britain, and War on Want invited Sir Herbert Broadley, the former Chief Executive of the FAO, to speak at one of its meetings in the House of Commons in February 1959 (subsequently publishing it as a pamphlet, The Hungry Millions). ${ }^{65}$

The launch of the Freedom from Hunger Campaign (FFHC) the following year, attendant with the beginning of the UN Development Decade, provided further stimulus as well as being the catalyst for many NGOs to reorient their attention from 
relief to longer-term development. ${ }^{66}$ In Britain, a thousand local FFHC Committees were set up, often assisted by the principal NGOs. The official slogan of the campaign had been the ancient proverb "Give a man a fish and you feed him for a day; teach him to fish, and you feed him for a lifetime." One would be hard pressed to discover a development NGO over the subsequent half-century that did not at one point reiterate this hackneyed mantra. ${ }^{67}$

Likewise, quotations from the key interventions in development debates can always be found throughout NGO literature. Gunnar Myrdal's arguments of 1957 were a key reference point for decades, but so too were the high-profile grand solutions to the world's problems that have frequently and regularly been published. From Lester Pearon's Partners in Development in 1969, through to Willy Brandt's NorthSouth (1980), Gro Brundtland's Our Common Future (1987), Julius Nyerere's South Commission (1987-99), and all the way through to the launch of the Millennium Development Goals (2000) and the Commission for Africa's Our Common Interest (2005), these key texts have been the bedrock of NGO campaigning. ${ }^{68}$ They have created the benchmarks against which national and international NGOs have attempted to hold governments accountable. It is an entirely understandable tactic, but one in which, when it comes to setting the terms of the debate, the NGO is being directed by the wording and conclusions of a number of - usually-elite political pronouncements.

A more fundamental accusation might also be lodged that the NGOs have been disingenuous about their own intellectual formation. Amartya Sen was supposedly crucial in the transition from needs to rights. He continues to be cited by Oxfam, especially his Development as Freedom. In 2002, in his capacity as honorary president of Oxfam, he wrote the foreword to Oxfam's Rigged Rules and Double Standards, and he was strongly cited as an influence in this publication. ${ }^{69}$ Yet one has to be skeptical about this influence. Sen himself is not convinced of the efficacy of rights, preferring instead improved communication based on social ethics and human freedom. ${ }^{70} \mathrm{In}$ 2009, he even said of his time at Oxfam, "I didn't do very much for them; actually they still say I am with them but I am not." 71 And indeed, Oxfam had fully embraced a language of rights in the early I990s long before Sen became its honorary president in 2000 .

The truth is that there was actually a rather lazy intellectual engagement with needs and rights, and Sen appeared to make an easy link with people's opportunities at the grassroots and the wider system of rights that could protect those capabilities. It is telling that in 1995, when Oxfam so centrally placed rights in its strategy document, staff were afterward invited to discuss how rights might inform their work; contrast this with the reading groups on liberation theology in the I970s that percolated upward into Oxfam policy. Perhaps Sen is frequently cited because of the ambivalent ways in which his broad principles might be put into concrete policy. Referring to a Nobel-winning economist who, crucially, can write in an accessible language is a form of self-flattery. And precisely because his capabilities approach is not rooted in specific proposals, it allows NGOs all too easily to cite it as the basis of a rights-based approach, as "agencies, by signing up to Sen's vision, remain uncommitted to anything more than improved discourse." 72 
If Sen does not provide the real intellectual genesis for NGOs' development thinking, the more likely explanation is that they have continued to work within the discourses of development articulated by the funding agencies. It serves a purpose to speak the language of the UNDP, the World Bank, and the other major donors of aid. One could argue that NGOs have adopted a rights-based agenda for a variety of instrumental purposes: to obtain money from donors; to speak the language of government in order to better influence policy; to be political without appearing too radical (or at least in a way that avoids the attention of the Charity Commissioners). It would then follow, from the perspective of the NGOs, that the lip-service paid to the global language of development does not actually have an impact on their work on the ground. To a certain extent, this has actually been the case. Many of the local initiatives of NGOs have continued to be similar to the "alternative" development projects pioneered in the I960s and I970s.

However, at the advocacy level, and in adapting the description of projects according to the language of rights, other changes in NGO operations have become apparent. One consequence has been the increasingly close relationship between nongovernmental and governmental sectors. Most significantly, official aid began to be channelled through NGOs. In 1975 OECD members channelled just 0.7 percent of their total aid budgets through NGOs. By 1986 this figure stood at 3.6 percent, and around 5 percent by $19944^{73}$ The intergovernmental agencies soon followed. In 1976, the EEC began co-financing international NGOs, and from 1975 to 1982 the World Bank involved six hundred and fifty NGOs in around one hundred World Bankfinanced projects. ${ }^{74}$

British levels of government funding of NGOs did not match the amounts disbursed in North America and Northern Europe. For instance, in the mid-1980s, government contributions to development NGOs as a percentage of official aid were less than I percent, whereas the figure was between 5 and Io percent for countries such as Canada, West Germany, the Netherlands, and the United States. Nevertheless, official funding became a significant component of British NGO income. In 1975, the Labour Government established the Joint Funding Scheme (JFS) which co-funded (usually 50 percent) projects submitted by British charities. In 1977, guaranteed block grants were also introduced to the larger NGOs, beginning with Oxfam and Christian Aid that year and extended to CAFOD in 1979 and the Save the Children Fund in 1985. The importance of the JFS, and the block grant within it, has increased gradually. By the end of the 1980s, the block grant was responsible for over 70 percent of all JFS Funds, and in 1989 "the JFS translated into support for more than nine hundred projects in over fifty countries, and included fifty projects specifically concerned with women." 75 Around one hundred charities were eligible to submit for co-funding.

Government funding of NGOs began because of the perceived limitations of the effectiveness of official aid that had become more widespread in the late 1960s and I970s. That it continued to expand is because it has fit the agendas of both the Labour and Conservative parties. Labour, with its long-standing connections to War on Want, was particularly well disposed to the NGOs. The Conservatives appreciated the role of NGOs because of traditional Tory skepticism toward official aid interventions. ${ }^{76}$ If 
government action was disliked, private intervention was encouraged. And if, as the Conservatives did, the official support for NGOs could be widely trumpeted, the government of the 1980 os could be seen to be doing something for international aid while at the same time cutting its overall official aid budget (as well as increasingly tying it to self-interested trade initiatives-the "aid and trade provision"). ${ }^{77}$

The consequence of higher levels of official funding was greater control of the sector. Often this control could be quite overt. British charity legislation has placed a number of restrictions on the political interventions of NGOs that have chosen to register as charities (famously, Amnesty International chose not to do so). War on Want, Christian Aid, and Oxfam frequently had their activities monitored, and they knew that at times they operated in defiance of the law. ${ }^{78}$ In the 1980 os, this attention increased, not least because Washington-based anticommunist organizations such as Western Goals and the International Freedom Foundation began to target NGOs for their supposed left-wing sympathies in their work in countries such as Israel, Nicaragua, and apartheid South Africa. ${ }^{79}$ The subsequent reports on Oxfam and War on Want have meant the NGOs have had to tread carefully in how they advertise and operate in countries of greater political tension. Indeed, since these Charity Commission investigations, both Oxfam and War on Want have, in the language of political science, operated more obviously as "insider" groups. ${ }^{80}$

The NGO sector has not been unaware of the issues involved in accepting government money. There has been a long and extensive debate within British NGO, policy, and academic circles about whether this relationship has been "too close for comfort." ${ }^{11}$ NGOs are said to lose their independence. Too great a reliance on official funding makes them susceptible to the political whims of governments. Essentially, the accusation is one of containment. It weakens the political role of NGOs and restricts their room for maneuver. ${ }^{82}$

The problem ought not to be overstated. NGOs have found ways to continue to operate politically. Notwithstanding the interventions of the Charity Commissioners, the principal charities stepped up their campaigning work in the 1980s. Together, in the early 1980s, they launched a campaign for "real aid." 83 Oxfam increasingly tackled the structural problems associated with world trade. ${ }^{84}$ And, of course, other NGOs such as the World Development Movement continued to work closely with the charities, while a seemingly politically innocuous body such as the Nicaragua Health Fund could have on its board of trustees representatives of explicitly political groups such as the Nicaragua Solidarity Campaign. ${ }^{85}$

A far more significant accusation, particularly in relation to the adoption of rightsbased agendas, is the charge that government funding makes the NGO indistinguishable from the official agency with respect to which it has previously claimed its distinctiveness and comparative advantage. ${ }^{86}$ Funding comes with conditions. Particularly from the perspective of the multilateral agencies operating during an era of structural adjustment programs, followed by the rise of the "Washington consensus," the role of NGOs has increasingly been seen as one of service provision. In order to get the contracts to provide such services, NGOs have had to share in the new dominant languages of development. Increasingly, since the end of the Cold War, this 
has been shaped by terms such as "good governance," "democracy," "civil society," and "participation."

Rights have provided the framework for bringing all of these terms together. In the sphere of international development this means that many of the established concerns of NGOs - about working with the very poor at the grassroots level in order to enable them to play a role in their own path to development-have been translated into a discourse of rights. Since NGOs believe such a politics emanates from their own intellectual formation, they have willingly spread the new language of development around the world. According to one investigation into the working practices of NGOs, they have become a transmission channel for the "donor fashions and new managerialism" promoted by official agencies and in which local groups must now couch their work..$^{87}$ The consequence is that the same discourses are found in the most improbable places all over the world..$^{88}$

A crucial aspect of this new transnational language is that it speaks more about the relationship NGOs have with their official donors than with the grassroots communities they are supposedly helping. A particularly contentious term has been "participation." It seems to refer to the classic collaborative operations of NGOs, yet it is a term that has been increasingly bandied around to secure funding. Because participation is demanded as a key element of good governance and democracy, often too hastily chosen partners have been selected who perhaps do not best represent the interests of the poorest members of a community. According to one critic, there has been "collusion in the manufacture of a collective dream of participation and community, behind the screen of which the levers of business remain quite intact. Better the warm allure of partnership than the discomforting blade of social analysis." 89 The rhetoric of instant partnership contrasts sharply with the long-term interaction and engagement with communities that many of these NGOs established in the 1960 and which enabled them to speak of their "comparative advantage" in the first place.

The role of NGOs in this standardization of development-speak has come under heavy criticism. It has been claimed that NGOs become implicated within a broader system of U.S. imperialism. The official support for NGOs is claimed to be not that dissimilar to the support received from Cold War governments for academic journals, conferences, and institutes..$^{90}$ Even writers favorably disposed to the work of NGOs have warned of the dangers of following practices promoted by the "Washington consensus." If NGOs have "become subcontractors of donors or government," then it is difficult to see how they are distinct from the institutional framework of Westernization and Americanization (whether real or perceived). ${ }^{91}$

The timing of NGOs' adoption of rights is therefore crucial. As the communist states collapsed in 1989, the Western powers connected to the OECD explored new modes of development cooperation. The OECD's Development Assistance Committee emphasized the "vital connection between open, democratic and accountable political systems, individual rights and the effective and equitable operation of economic systems." 92 Now developing countries were placed alongside those in Eastern Europe in a policy directed, as the OECD ministers themselves put it, "towards the basic values which are common to the OECD countries: pluralistic 
democracy, respect for human rights, and a competitive market economy. They improve the prospect of a truly integrated global economic system." ${ }^{33}$ If these terms had become the benchmarks of global governance, it is of little surprise that so many NGOs had made human rights so central to their mission statements by 1993, the same year that the Vienna Declaration on Human Rights was made.

Undoubtedly, one outcome of an increasingly shared language of development between the official and the unofficial agencies was that NGOs expanded, sometimes exponentially, during the I990s. For instance, the combined total income of Oxfam, Tearfund, Christian Aid, CAFOD, Save the Children, and the British Red Cross more than doubled in the fifteen years following $1989 .{ }^{94}$ They have been derided as the "big international NGOs" or BINGOs that "now resemble the predatory transnational corporations they have often quite consciously come to ape." 95 Along with growth, then, has also come criticism. NGOs have supposedly lost their critical edge. This tendency has only been heightened with the rise of a post-200I security agenda that has seen NGOs increasingly likely to follow in the wake of military personnel, setting up camp in conflict zones around the world, especially Afghanistan. ${ }^{96}$ If it has seemed too far-fetched to equate the objectives of still well-respected NGOs such as Oxfam with the imperatives of U.S. foreign policy, others have commented on how NGOs have spread the language and the techniques of global governance around the world and to the micro-level. That is, a literature focused on "governmentality" has observed the extent to which NGOs are as much a part of the system of global governance as a critic of it in a manner similar to the missionary bodies of a prior, imperial age. ${ }^{97}$ It is an issue as yet unresolved, with commentators still asking whether the rights-based agenda represents a "new form of conditionality" for aid beneficiaries. ${ }^{98}$

What is more obvious is that NGOs have become increasingly indistinguishable from one another. To be sure, development NGOs have always networked and collaborated, or at least have done so from the creation of the Voluntary Committee on Overseas Aid and Development in 1965. Likewise, they have published joint statements, especially in response to agenda-setting international initiatives such as the Brundtland Report. ${ }^{99}$ More specifically, the confusion among the general public as to whether Christian Aid is "Oxfam with hymns" goes back decades. ${ }^{100}$ But the differences between Christian Aid, War on Want, Oxfam, and several other NGOs on issues such as Africa or the world trade system are barely noticeable. ${ }^{101}$ As a consequence, the number of co-produced books and pamphlets has increased substantially over the last two decades. ${ }^{102}$ This counters a noted lack of coordination often commented upon in the I970s, but it raises questions as to why there continue to be so many different NGOs and whether the internal logic of an organization is geared toward self-perpetuation rather than the pressing needs of the issue at hand.

It would be a mistake to think that NGOs have entered into a world of rights blindly or unaware of the consequences. NGOs are not afraid of levelling the harshest criticisms against themselves. As the development and human rights activist Firoze Manji put it in Development in Practice in 1998, "The fact is that many NGOs have, unwittingly or wittingly, inserted themselves over the last few decades as part of the very infrastructure of the political economy that reproduces the unequal social relations of post-colonial Africa." 103 
The application of a rights-based agenda has thus been matched by a continuing anguish over the problems of such rights. ${ }^{104}$ Yet for all this, the NGOs have also persisted in their use of human rights frameworks. Rights are, it would seem, in Samuel Moyn’s phrase, “a last utopia." But it is a utopianism shaped by a language from above and one in which the ideals are always known to fail to match the reality. On the ground, NGOs know from bitter experience the difficulties in marrying political and civil rights with economic and social rights. Yet they continue to use the language of rights, as it adds a veneer of radicalism to their own agendas, covering too the priorities of an official aid policy to which they have become increasingly beholden.

\section{Beyond the Two Narratives}

What we can see from the above, then, are two competing accounts of the rise to ascendancy of rights-based approaches within the development community. On the one hand, from the perspective of the NGOs' own publicity, rights emerged as the intellectual underpinning of their efforts to "scale up" their work on the ground to their political objectives targeted at the very structure of global governance. On the other hand, a more complex story emerges of how civil and political rights became tools of international diplomacy in the I970s, to be combined with greater emphasis on economic and social rights in a post-Cold War context.

On balance, and without discounting entirely the many genuine and passionately felt reasons for adopting a language of rights, it is very much the latter story that has prevailed. Too often the engagement with rights by NGOs has been intellectually superficial. This may be understandable - these are, after all, committed, pragmatic bodies without the time or resources to commit to academic reflection-but it suggests that the translation of needs into rights served a practical purpose at a time when the distinctions between official and unofficial aid became increasingly blurred. If an engagement in rights talk had little impact on actual development projects on the ground, then we might admire the canniness of NGOs in navigating a post-Cold War system of global governance. But it is more likely that rights talk both traps the NGOs in certain forms of contractual relationship with the institutions of global governance and prevents the articulation of radical alternative political solutions, ones founded on models of social justice that contradict the fundamental principles of a system of global governance itself founded on market-based democratic individualism. To put it bluntly, development NGOs have made themselves central players in the game of rights, but this is a sport — as weaker NGOs have long realized-that is played out in arenas built by more powerful backers and according to rules designed by agents other than the NGOs themselves. ${ }^{105}$

Two consequences of this account are apparent. The first is a historical one. While the central importance of the I970s in recent historical writing is not disputed, it would be overstating the case that the decade triggered an embrace of rights - both economic, social, and cultural, as well as political and civil—by all types of transnational social movement. What the two narratives above demonstrate is that rights came to prominence because they served the purposes of a variety of actors. And in this sense, the decade after 1989 also represents as crucial a period as that of the 1940 os 
and the I970s in the history of rights. Only then did the rhetoric of rights fully embrace both civil and political rights and economic and social rights. If recent work on rights has shown their constant evolution and relative youth (in their current form), then a case study on international aid and development has shown just how recent this history is.

A second point is targeted more at the role of the NGOs themselves. There has been a long-standing debate about the effectiveness of aid. In recent years this has taken on more populist form, though it has been influenced heavily by works of anthropology and political economy demonstrating that while technical assistance has "depoliticised" development, it has also ensured the perpetuation and expansion of the aid agencies concerned. ${ }^{106}$ Mainly the accusations that aid does not work have been levelled at the official agencies. But as the differences between official and unofficial aid have been blurred, then so have the accusations about the ineffectiveness of aid been levelled at NGOs too. This has largely been about their work in emergency situations, suggesting that their interventions can perpetuate the conditions which give rise to the crisis in the first place. ${ }^{107}$ But as one account of Oxfam and Christian Aid's ongoing support for Ujaama in the I970s implies, more detailed assessments might begin to be made of the overall effectiveness of NGOs' development work. ${ }^{108}$ The public trust placed in NGOs because they do "good works" may soon diminish if they become closely associated with some of the failures of large-scale official intervention.

One basis for such a criticism might rest precisely on the rights-based approach adopted by NGOs. Clearly, sharing in the language of rights has been one of the reasons for the massive growth and proliferation of NGOs over the last two decades. But while those that have adopted rights for their modus operandi might well now enjoy the benefits of insider status, they will also increasingly become the targets of those who see them giving up on an alternative approach. The accusations against rights are well established. They appeal especially to those who wish to critique rather than overhaul the existing system of liberal market democracies. ${ }^{109}$ For Thomas Pogge, because basic rights, as we have seen advocated by NGOs, are based on human needs, they commit us to ensure that we do not "disrespect" these rights, either in all of us or in sections of the population. This is essentially the negative duty of rights: that we refrain from violating the rights of others. What such a position does not demand is the more positive duty whereby we accept our responsibility for protecting the rights of others and work to ensure the establishment of a social system within which "all its participants have secure access to the objects of their human rights." ${ }^{110}$ For NGOs, this is precisely why they adopted a rights-based approach - to be more political and to challenge the very principles of global governance. It would be an irony indeed, though perhaps entirely understandable from the second narrative above, if the adoption of a rights-based framework prevented exactly such a critique from being articulated.

\section{NOTES}

I. Mark Mazower, No Enchanted Palace: The End of Empire and the Ideological Origins of the United Nations (Princeton, N.J.: Princeton University Press, 2009). 
2. Oxfam International, Towards Global Equity: Strategic Plan, 200I-2004 (Oxford: Oxfam, 200I).

3. See http://www.waronwant.org/about-us (accessed September 30, 20I0).

4. See http://www.christianaid.org.uk/aboutus/who/aims/our_aims.aspx (accessed September 30, 2010).

5. See http://www.actionaid.org.uk/I00002/about_us.html (accessed September 30, 2010).

6. World Development Movement, World Development Movement Plus: A Ten Year Vision Guidance for Future WDM Leaders (London: WDM, 2009).

7. See http://www.oneworldaction.org/who_we_are (accessed September 30, 20I0).

8. Samuel Moyn, The Last Utopia: Human Rights in History (Cambridge, Mass.: Harvard University Press, 20Io), 9. See also Niall Ferguson et al., eds., The Shock of the Global: The I97os in Perspective (Cambridge, Mass.: Harvard University Press, 2010).

9. Emma Harris-Curtis, Oscar Marleyn, and Oliver Bakewell, The Implications for Northern NGOs of Adopting Rights-Based Approaches (Oxford: INTRAC, 2005); Emma Harris-Curtis,

"Rights-Based Approaches: Issues for NGOs," Development in Practice I3, no. 5 (2003): 558-64.

Io. David P. Forsythe, The Humanitarians: The International Committee of the Red Cross (Cambridge: Cambridge University Press, 2005); Peter J. Burnell, Charity, Politics and the Third World (London: Harvester Wheatsheaf, I99I); Clare Saunders, "British Humanitarian, Aid and Development NGOs, 1949-Present," in NGOs in Contemporary Britain: Non-State Actors in Society and Politics since 1945, ed. Nicholas Crowson, Matthew Hilton, and James McKay (Basingstoke: Palgrave Macmillan, 2009), 38-58.

II. Maggie Black, A Cause for Our Times: Oxfam, the First Fifty Years (Oxford: Oxford University Press, 1992).

I2. Janet Lacey, Christian Aid (London: Edinburgh House, 196I), 7-9; Michael Taylor, Not Angels but Agencies: The Ecumenical Response to Poverty: A Primer (London: SCM Press, 1995), 5-7.

13. Mike Hollow, A Future and a Hope: The Story of Tearfund, and Why God Wants the Church to Change the World (Oxford: Monarch, 2008).

14. Mark Luetchford and Peter Burns, Waging the War on Want: Fifty Years of Campaign against World Poverty (London: War on Want, 2003).

I5. Peter Catterall, "The Distinctiveness of British Socialism? Religion and the Rise of Labour, c. 1900-39," in The Foundations of the British Labour Party: Identities, Cultures and Perspectives, 1900-39, ed. Matthew Worley (Aldershot: Ashgate, 2009), I3I-52.

I6. Haslemere Committee, The Haslemere Declaration (London: Haslemere Committee, I968), 5 .

17. Ibid.

I8. Ibid., 4.

19. Robin Poulton and Michael Harris, Putting People First: Voluntary Organisations and Third World Organisations (Basingstoke: Macmillan, 1989).

20. Gunnar Myrdal, Economic Theory and Under-Developed Regions (London: Methuen, I957/ 1963).

2I. E. F. Schumacher, Small Is Beautiful: A Study of Economics as if People Mattered (London: Abacus, 1974/1973); Christian Aid, Small Is Beautiful: Simple Aids for World Development (London: Christian Aid, 1978); Ivan Illich, Disabling Professions (London: Boyars, 1977).

22. Paolo Freire, Pedagogy of the Oppressed (New York: Continuum, 1970).

23. Black, Cause for Our Times, 183 . 
24. Ibid., I95.

25. Luetchford and Burns, Waging the War on Want, 53.

26. Michael Jennings, Surrogates of the State: NGOs, Development and Ujamaa in Tanzania (Bloomfield, Conn.: Kumarian, 2008).

27. Rutherford M. Poats, Twenty-Five Years of Development Co-operation: A Review of the Efforts and Policies of the Members of the Development Assistance Committee (Paris: OECD, 1985), I $5 \mathrm{I}-54$.

28. Organisation for Economic Co-operation and Development, Voluntary Aid for Development: The Role of Non-Governmental Organisations (Paris: OECD, I988), 5.

29. Bertrand Schneider, The Barefoot Revolution: A Report to the Club of Rome (London: Intermediate Technology Publications, 1988), xiii.

30. Ibid., 224.

31. Matthew Hilton et al., The Politics of Expertise: How NGOs Shaped Modern Britain (Oxford: Oxford University Press, 2013).

32. Cited in Ben Whitaker, Bridge of People: A Personal View of Oxfam's First Forty Years (London: Heinemann, 1983), 26.

33. Black, Cause for Our Times, 155-62.

34. Mike Muller, The Baby Killer (London: War on Want, 1974); Edith Bond, The State of Tea (London: War on Want, 1974); Andy Chetley, The Baby Killer Scandal (London: War on Want, 1979).

35. James McKay, "Voluntary Politics: The Sector's Political Function from Beveridge to Deakin," in Beveridge and Voluntary Action in Britain and the Wider World, ed. Melanie Oppenheimer and Nicholas Deakin (Manchester: Manchester University Press, 20II), 80-93.

36. Alf McCreary, Up-With People: Christian Aid around the World (London: Fontana, I979), I88.

37. Jane Freeland, A Special Place in History: The Atlantic Coast in the Nicaraguan Revolution (London: Nicaragua Solidarity Campaign/War on Want, I988); Nicky Parker, ed., Silent No Longer: Central America Today (London: War on Want, 1989).

38. Christian Aid, Policy Briefing: Child Labour (London: Christian Aid, 200I).

39. Julia Cleves Mosse, Half the World, Half a Chance: An Introduction to Gender and Development (Oxford: Oxfam, 1993); Tina Wallace and Candida March, eds., Changing Perceptions: Writings on Gender and Development (Oxford: Oxfam, I991); Helen O'Connell, Dedicated Lives: Women Organising for a Fairer World (Oxford: Oxfam, 1993).

40. Luetchford and Burns, Waging the War on Want, II3; Jane Deighton et al., Sweet Ramparts: Women in Revolutionary Nicaragua (London: Nicaragua Solidarity Campaign/War on Want, I983); Helen O'Connell, Just Ordinary Feminists: Women in Peru and Bolivia Face the Debt Crisis (London: War on Want, I990).

4I. Amartya Sen, Development as Freedom (Oxford: Oxford University Press, 1999), I54.

42. Susan Ariel Aaronson and Jamie M. Zimmerman, "Fair Trade? How Oxfam Presented a Systemic Approach to Poverty, Development, Human Rights, and Trade," Human Rights Quarterly 28, no. 4 (2006): I009; Susan H. Holcombe, "Capabilities and Human Rights Approaches: Competing Paradigms or Re-Enforcing Models," Projections 8 (2008): I04-I3.

43. Maxine Molyneux and Sian Lazar, Doing the Rights Thing: Rights-Based Development and Latin American NGOs (London: ITDG, 2003), 4.

44. Ian Anderson, "Oxfam, the World Bank and Heavily Indebted Poor Countries," in NGOs 
as Advocates for Development in a Globalising World, ed. Barbara Rugendyke (London: Routledge, 2007), I23.

45. Matthew Hilton, Prosperity for All: Consumer Activism in an Era of Globalization (Ithaca, N.Y.: Cornell University Press, 2009); Christopher Rootes and Clare Saunders, "The Global Justice Movement in Great Britain," in The Global Justice Movement: Cross-National and Transnational Perspectives, ed. Donatella Della Porta (Boulder, Co.: Paradigm, 2007), I28-56; Paola Grenier, "Jubilee 2000: Laying the Foundations for a Social Movement," in Globalising Civic Engagement: Civil Society and Transnational Action, ed. John Clark (London: Earthscan, 2003), 86-108.

46. Luetchford and Burns, Waging the War on Want, 176.

47. John Gwynn, Introducing Oxfam (Oxford: Oxfam, 1993), I.

48. Deborah Eade and Suzanne Williams, The Oxfam Handbook of Development and Relief, vol. I (Oxford: Oxfam, 1995), 25.

49. Pat Simmons, Words into Action: Basic Rights and the Campaign against World Poverty (Oxford: Oxfam, 1995).

50. War on Want, Iraq: Sanctions and Human Rights (London: War on Want, 1995), I.

5I. Ibid.

52. Rosemary McGee, Clive Robinson, and Arthur van Diesen, Distant Targets? Making the Twenty-First-Century Development Strategy Work (London: Christian Aid, 1998).

53. Oxfam International, Towards Global Equity: Strategic Plan, 200I-2004 (Oxford: Oxfam, 200I); Susan Ariel Aaronson and Jamie M. Zimmerman, "Fair Trade? How Oxfam Presented a Systemic Approach to Poverty, Development, Human Rights, and Trade," Human Rights Quarterly 28, no. 4 (2006): 998-1030.

54. ActionAid, Fighting Poverty Together 1999-2005: ActionAid Strategic Plan (London: ActionAid, 1999), I2.

55. Pat Carey, CARE International, November Io, 2000, quoted in Emma Harris-Curtis, Oscar Marleyn and Oliver Bakewell, The Implications for Northern NGOs of Adopting Rights-Based Approaches (Oxford: INTRAC, 2005), 15.

56. D. J. Morgan, The Official History of Colonial Development, vol. 4, Changes in British Aid Policy (Basingstoke: Macmillan, 1980); Jim Tomlinson, "The Commonwealth, the Balance of Payments and the Politics of International Poverty: British Aid Policy, 1958-1971," Contemporary European History 12, no. 4 (2003): 413-29; Gilbert Rist, The History of Development: From Western Origins to Global Faith, 3rd ed. (London: Zed, 2008), 78.

57. Paul Gready and Jonathan Ensor, "Introduction," in Reinventing Development? Translating Rights-Based Approaches from Theory into Practice, ed. Gready and Ensor (London: Zed, 2005), 17.

58. Rist, History of Development, 162-69; Katrin Lederer, Johan Galtung, and David Antal, eds., Human Needs: A Contribution to the Current Debate (Cambridge: Oelenschlager Press, 1980).

59. Gready and Ensor, "Introduction," I8.

6o. International Commission of Jurists, Development, Human Rights and the Rule of Law (Oxford: Pergamon, 1981).

6I. United Nations General Assembly, "Declaration on the Right to Development," 97th Plenary Meeting, December 4, 1986, A/RES/4I/I28.

62. United Nations General Assembly, World Conference on Human Rights, "Vienna declaration and programme of action," July I2, 1993, A/CONF.157/23.

63. Stephen P. Marks and Bård A. Andreaassen, "Introduction," in Development as a Human 
Right: Legal, Political and Economic Dimensions, ed. Andreaassen and Marks (Cambridge, Mass.: Harvard School of Public Health, 2006), vi-xxii.

64. André Frankovits, Mainstreaming Human Rights: The Human Rights-Based Approach and the United Nations System (Sydney: Human Rights Council, 2005); DFID, Realising Human Rights for Poor People (London: DFID, 200o); Laure-Hélène Piron and Francis Watkins, DFID Human Rights Review: A Review of How DFID Has Integrated Human Rights into Its Work (London:

Overseas Development Institute, 2004).

65. Lacey, Christian Aid; Janet Lacey, Refugees: Still They Come (London: Edinburgh House 1963); Black, Cause for Our Times, 59; Luetchford and Burns, Waging the War on Want, 37.

66. Black, Cause for Our Times, 70.

67. OECD, Voluntary Aid for Development, 2I; Lacey, Christian Aid, I3; Leonard Hurst, Hunger (London: Edinburgh House, 196I).

68. Commission on International Development, Partners in Development (London: Pall Mall Press, 1969); Independent Commission on International Development Issues, North-South: A Programme for Survival (London: Pan, 1980); World Commission on Environment and Development, Our Common Future (Oxford: Oxford University Press, 1987); Commission for Africa, Our Common Interest (London: Penguin, 2005).

69. Oxfam, Rigged Rules and Double Standards: Trade, Globalisation and the Fight Against Poverty (Oxford: Oxfam, 2002), 22.

70. Amartya Sen, "Human Rights and Development," in Andreaassen and Marks, eds., Development as a Human Right, I-8.

71. Quoted in Christian Sarkar, "Amartya Sen: The Idea of Justice," SOA World Magazine, October 29, 2009, available at http://soa.syscon.com/node/II54I39 (accessed July 23, 20I0).

72. Peter Uvin, Human Rights and Development (Bloomfield, Conn.: Kumarian, 2004), I25.

73. Michael Edwards and David Hulme, "Too Close for Comfort? The Impact of Official Aid on Nongovernmental Organizations," World Development 24, no. 6 (1996): 96I-73.

74. Smith, More than Altruism: The Politics of Private Foreign Aid (Princeton, N.J.: Princeton University Press, 1990), 4; Poats, Twenty-Five Years.

75. Burnell, Charity, Politics and the Third World, 209.

76. See, for instance, the work of Peter Bauer, who was made a life peer by Margaret Thatcher in 1973: Bauer, Dissent on Development: Studies and Debates in Development Economics (London: Weidenfeld and Nicholson, 197I).

77. Essays by Burnell and Toye in Britain's Overseas Aid since 1979: Between Idealism and SelfInterest, ed. Anuradha Bose and Peter Burnell (Manchester: Manchester University Press, 199I), I-3I, 97-I24.

78. War on Want Mss: "Legal Restrictions on Campaigning: The Attitude Taken by War on Want," September 1979, Box I05, File I028.

79. Luetchford and Burns, Waging the War on Want, I43; International Freedom Foundation, A Multitude of Sins, plus accompanying letter, March 22, 1989, cited in Chris Dolan, "British Development NGOs and Advocacy in the 1990s," in Making a Difference: NGOs and Development in a Changing World, ed. Michael Edwards and David Hulme (London: Earthscan, 1992), 203-10.

80. Charity Commissioners for England and Wales, War on Want: Report of an Inquiry Submitted to the Commissioners, Isth February I9gI (London: HMSO, 199I); Peter Burnell, "Charity Law and Pressure Politics in Britain: After the Oxfam Inquiry," Voluntas 3, no. 3 (1992): 3II-34.

8I. Edwards and Hulme, "Too Close for Comfort?" 
82. Peter Burnell, "Debate: Third World Charities in Britain towards 200o," Community Development Journal 28, no. I (1993): 66-8I; Smith, More than Altruism; Burnell, Foreign Aid; Doug Hellinger, "NGOs and the Large Aid Donors: Changing the Terms of Engagement," World Development I5, supplement (1987): 135-43.

83. Independent Group on British Aid, Real Aid: A Strategy for Britain (London: Independent Group on British Aid, I98I); and Aid Is Not Enough: Britain's Policies to the World's Poor (London: Independent Group on British Aid, 1984).

84. For instance, John Clark, For Richer, for Poorer: An Oxfam Report on Western Connections with World Hunger (Oxford: Oxfam, 1986).

85. Burnell, Charity, Politics and the Third World, 246.

86. Tina Wallace, Sarah Crowther, and Andrew Shepherd, Standardising Development: Influences on UK NGOs' Policies and Procedures (Oxford: WorldView, 1997).

87. Janet G. Townsend, Gina Porter, and Emma Mawdsley, "The Role of the Transnational Community of Non-Governmental Organisations: Governance or Poverty Reduction?" Journal of International Development I4, no. 6 (2002): 829-39.

88. Terje Tvedt, Angels of Mercy or State-Financed Development Diplomats? NGOs and Foreign Aid (Oxford: Currey, 1998).

89. Paul Francis, "Participatory Development at the World Bank: The Primacy of Process," in Participation: The New Tyranny?, ed. Bill Cooke and Uma Kothari (London: Zed, 2004), 80.

90. Nicolas Guilhot, The Democracy Makers: Human Rights and International Order (New York: Columbia University Press, 2005).

9I. David Lewis and Tina Wallace, "Introduction," in New Roles and Relevance: Development NGOs and the Challenge of Change, ed. Lewis and Wallace (Bloomfield, Conn.: Kumarian, 2000), xi.

92. Cited in Helmut Führer, The Story of Official Development Assistance (Paris: OECD, 1996), 59 .

93. Ibid.

94. For more detailed statistical evidence of this kind on development NGOs, plus all other types of NGO operating in Britain, see Matthew Hilton, Nicholas Crowson, Jean-François Mouhot, and James McKay, eds., A History of NGOs in Britain: Charities, Civil Society and the Voluntary Sector since 1945 (Basingstoke: Palgrave Macmillan, 2012).

95. David Ransom, "The Big Charity Bonanza," New Internationalist, no. 383 (October 2005), available at http://www.newint.org/features/2005/I0/or/keynote (accessed September 22, 2009).

96. Anthony J. Bebington, Samuel Hickey, and Diana C. Mitlin, eds., Can NGOs Make a Difference? The Challenge of Development Alternatives (London: Zed, 2008).

97. Raymond L. Bryant, "Non-Governmental Organizations and Governmentality: 'Consuming' Biodiversity and Indigenous People in the Philippines,' Political Studies 50, no. 2 (2002): 268-92; Firoze Manji and Carl O’Coill, "The Missionary Position: NGOs and Development in Africa," International Affairs 78, no. 3 (2002): 567-83; Giles Mohan, "The Disappointments of Civil Society: The Politics of NGO Intervention in Northern Ghana," Political Geography 21, no. I (2002): 125-54.

98. Giles Mohan and Jeremy Holland, "Human Rights and Development in Africa: Moral Intrusion or Empowering Opportunity?" Review of African Political Economy 28, no. 88 (200I): I77-96. 
99. Friends of the Earth et al., Britain and the Brundtland Report: A Programme of Action for Sustainable Development (London: International Institute for Environment and Development, I988).

Ioo. Taylor, Not Angels but Agencies, Ioo.

IOI. See, for instance, the following on the world's trading system: Belinda Coote with Caroline LaQuesne, The Trade Trap: Poverty and the Global Commodity Markets (Oxford: Oxfam, 1996/1992); Peter Madden, A Raw Deal: Trade and the World's Poor (London: Christian Aid, I992); or the following on plans for Africa (separated by over a decade): Oxfam, Africa, Make or Break: Action for Recovery (Oxford: Oxfam, 1993); Christian Aid, A Rethink of Trade and Governance: Christian Aid's Position on the Africa Commission (London: Christian Aid, 2004).

I02. For example, Henry Northover et al., A Joint Submission to the World Bank and IMF Review of HIPC and Debt Sustainability (London: CAFOD et al., 2002); Christian Aid et al., Breaking the Curse: How Transparent Taxation and Fair Taxes Can Turn Africa's Mineral Wealth into Development (London: Christian Aid et al., 2009); ActionAid International et al., Kept in the Dark: A Briefing on Parliamentary Scrutiny of the IMF and World Bank (London: ActionAid International et al., 2005).

I03. Firoze Manji, “The Depoliticisation of Poverty,” in Development and Rights, ed. Deborah Eade (Oxford: Oxfam, I998), 25.

I04. Guilhot, Democracy Makers; Sam Hickey and Diana Mitlin, eds., Rights-Based Approaches to Development: Exploring the Potentials and Pitfalls (Sterling, Va.: Kumarian, 2009).

I05. I discuss these issues in a parallel case (that of consumer rights) and at much greater length in the final chapters of Hilton, Prosperity for All.

I06. William Easterly, The White Man's Burden: Why the West's Efforts to Aid the Rest Have Done So Much Ill and So Little Good (Oxford: Oxford University Press, 2006); James Ferguson, The Anti-Politics Machine: "Development," Depoliticization, and Bureaucratic Power in Lesotho (Minneapolis: University of Minnesota Press, 1994).

I07. Michael Maren, The Road to Hell: The Ravaging Effects of Foreign Aid and International Charity (New York: Free Press, 1997); Linda Polman, War Games: The Story of Aid and War in Modern Times (London: Viking, 20I0).

I08. Jennings, Surrogates of the State; Overseas Development Institute, The Impact of Overseas NGO Development Projects (London: ODI, 1996).

I09. Ian Shapiro, The Evolution of Rights in Liberal Theory (Cambridge: Cambridge University Press, I986).

IIo. Thomas W. Pogge, World Poverty and Human Rights: Cosmopolitan Responsibilities and Reforms (Cambridge: Polity, 2002), 66. 